Małgorzata Filipek*

Instytut Filologii Słowiańskiej

Uniwersytet Wrocławski, Polska
УДК 821.163.41-992.09 Vučković R. DOI: $10.19090 /$ gff.2017.1.35-47

Стручни научни рад

\title{
ШПАНИЈА У ПУТОПИСНОЈ ПРОЗИ РАДОВАНА ВУЧКОВИЋА
}

Предмет овог рада је слика Шпаније у књизи Читање градова (2010) угледног књижевног историчара и теоретичара авангарде Радована Вучковића (1935-2016). Посећујући шпанске градове - Мадрид, Толедо, Барселону, Фигерес и Ђирону - аутор се уједно укључује у богату српску путописну традицију о овој земљи (Р. Петровића, И. Андрића, М. Црњанског, Ј. Дучића). Структура Вучковићеве књиге има највише сродности са Дучићевим путописом Градови и химере, где су историјске личности и збивања из прошлости важнији од савремености. Уједно, указује се и на начин коришћења бројних интертекстуалних референци из књижевности и културе са којима аутор ступа у дијалог, као и пишчева специфична перцепција шпанских градова. Циљ рада је да се поетички осветли овај запостављени путопис савремене српске књижевности у поређењу са наведеним ауторима, пре свега са Јованом Дучићем.

Кључне речи: Радован Вучковић, Шпанија, слика, Дучић

Иберијско полуострво као одредиште нашло се у кругу интересовања Срба почетком XX века. ${ }^{1}$ Нешто касније, нарочито 20-тих и 30-тих година појавила су се многа дела чији аутори су имали прилику да упореде своју представу о Шпанији са стварношћу. Најважнији догађај који је доспео у средиште пажње јавног мнења био је Шпански грађански рат (1936-1939). Описивали су га дописници ${ }^{2}$ и добровољци из Југославије који су се борили на страни Републике. ${ }^{3}$

\footnotetext{
*margo115@wp.eu

${ }^{1}$ 1905. Светозар Зорић штампао је у „Српском књижевном гласнику” (књ. XIV, св. 9, 10; књ. $\mathrm{XV}$, св. 2, 3, 9, 11, 12) своје утиске из Шпаније, посвећене углавном Андалузији.

2 О рату су писали 1937. Милош Црњански (циклус У Шианији 1937.) чији су текстови ретки пример погледа на ратна збивања у Шпанији са антирепубликанске тачке гледишта и Ото Бихаљи-Мерин, чија се књига Шпанија између смрти и рађања појавила прво на немачком и енглеском језику а на српском у Југославији тек 1946.

${ }^{3}$ Седамедесетих се појавило пет томова успомена добровољаца Шианија (1936-1939). Зборник сећања југословенских добровољаца у шпанском рату (Београд 1971).
} 
Резолуција Генералне скупштине ОУН-а која је тражила од држава да се прекину дипломатски односи са режимом генерала Франсиска Франка ${ }^{4}$ (Francisco Franco) ограничила је након Другог светског рата путовања у Шпанију, а писци из Југославије имали су прилику да отпутују тамо тек 70тих година прошлога века ${ }^{5}$.

Радован Вучковић (1935-2016), истакнути истраживач књижевности модернизма и експресионизма, ${ }^{6}$ познавалац Андрићевог књижевног опуса, у књизи Читање градова. Дневник путовања ${ }^{7}$ наставио је кретање путем ствараоца путописне прозе ${ }^{8}$ који је започео 90-тих година XX века. Књига Читање градова. Дневник путовања састоји се од више од осамдесет записа из многих градова Европе, ${ }^{9}$ које је писац посетио од 2. априла 2008. до 10. априла 2010.

Већ пре путовања у Шпанију Вучковић је дошао до закључка да су га информације о тој земљи пратиле од раног детињства, а разлог им је био Шпански грађански рат. У школско доба Вучковић је имао прилику да чита

${ }^{4}$ T. Miłkowski, P. Machcewicz, Historia Hiszpanii, Wrocław, 1998: 394.

${ }^{5}$ Своје утиске забележили су М. Кујунџић [Беле куће и ирни бикови, „Летопис Матице српске", г. 147, књ. 407, св. 4, април 1971, с. 197-231] и М. Поповић [Пут у Шпанију, [у:] Путописни дневници, Београд 2006: 139-157]. 80-тих су се појавиле књиге двеју списатељица: Гордане Куић за коју је Шпанија праотаџбина сефардских предака и Гордане Ћирјанић за коју је ова земља отаџбина њеног мужа и ћерке.

6 Упоредити Р. Вучковић, Андрић. Историја и личност, Београд 2002; Андрић: паралеле и рецепџија, Београд 2006; Поетика хрватског и српског експресионизма, Сарајево 1979; Модерна драма, Сарајево 1982; Даница и друге звијезде, Загреб 1980; Крлежина дела, Сарајево 1986; Авангардна поезија, Бања Лука 1989; Од Ћоровића до Ћопића, Сарајево 1989; Модерна српска проза: крај 19. и почетак 20. века, Београд 1990; Српска авангардна проза, Београд 2000; У знаку традиције и авангарде, Београд 2004; Модерни роман 20. века, Источно Сарајево 2005; Војвођанска књижевна авангарда, Зрењанин 2006; Паралеле и укрштавања, Нови Сад 2009.

${ }^{7}$ Р. Вучковић, Читање градова. Дневник путовања, Београд 2010. Сви цитати потичу из овог издања књиге.

8 Збогом, Сарајево (1994, 2012); У невремену: дневнички записи, Београд 2004; Пут на Исток. Дневник путовања (2012).

9 На Вучковићевој мапи света налазе се следећи градови: Требиње, Дубровник, Београд, Праг, Карлови Вари, Беч, Херцег Нови, Подгорица, Сјеница, Нови Пазар, Чачак, Бања Лука, Верона, Пиза, Рим, Фиренца, Венеција, Грац, Сарајево, Истанбул, Атина, Микена, Делфи, Салцбург, Париз, Минхен, Берлин, Загреб, Петроград, Мадрид Москва, Толедо, Барселона, Фигерес, Герона, Копенхаген, Стокхолм, Порто, Гимареш, Лисабон, Синтра, Евора, Брага, Коимбра. 
роман о племићу из Ла Манче који је много година касније постао предмет његове научне анализе. ${ }^{10}$ Размишљајући о земљи коју је назвао „непознати део Европе" (Читағе градова, 2010: 246), Вучковић се надовезивао на дела писаца шпанског,златног доба" - Лопеа де Веге, Педра Калдерона де ла Барке и Луиса де Гонгоре, као и на текстове Иве Андрића, Јована Дучића, Растка Петровића и Милоша Црњанског који су писали „са топлином о шпанским пејзажима, местима и ликовима" (Читање градова, 2010: 348).

Вучковићеви записи о Шпанији резултат су екскурзије у којој је учествовао између 29. децембра 2009. и 5. јануара 2010. Пишчев сусрет са Шпанијом почео је у Мадриду, а завршио се у Барселони. Аутор је тематизовао сваки од осам дана проведених у Шпанији посветивши му засебан запис, где је обележио тачан датум и место боравка (Мадрид, Мадрид, Толедо-Мадрид, Мадрид, Барселона, Фигерес-Ђирона, Барселона, Барселона).

Обилазак знаменитости увек прати историјска рефлексија. Аутор у својим записима рекапитулира прошлост Иберијског полуострва - римско доба, времена владавине Вандала, Визигота и Арабљана на Полуострву, векове хришћанске реконкисте, која се завршила освајањем Гранаде 1492. године, Колумбову експедицију, владавину Хабсбурга и Бурбона, борбу с Наполеоновом војском, губитак прекоокеанских територија и године II Републике (1931-1939) коју је након братоубилачког рата заменила диктатура генерала Франка окончана његовом смрћу 1975. године.

Учешће у екскурзији ограничава покушај индивидуализације путничке праксе, стога је Вучковић, као члан организоване групе, упознавао непознати простор према одређеној схеми. ${ }^{11}$ И зато се, након доласка у Мадрид и Барселону, возио аутобусом по граду, стижући у најтипичнија туристичка места. Своја индивидуална интересовања реализовао је током усамљених шетњи улицама, када су остали учесници одлазили у куповину или се одмарали у хотелу.

Туриста у непознатом простору увек зависи од времена које му је на располагању. ${ }^{12}$ Строг режим организоване екскурзије чини да је време за

10 Р. Вучковић, Један аспект лика Сервантесовог Дон Кихота, [у:] Р. Вучковић, Проблеми, писии, дела, II, Сарајево 1976: 103-111.

${ }^{11}$ R. Barthes, Błękitny przewodnik, [w:] Tenże, Mitologie, thum. A. Dziadek, Warszawa 2000: 157.

${ }^{12}$ K. H. Wojciechowski, Problem percepcji $i$ oceny estetycznej krajobrazu, Lublin 1986: 101. 
разгледање тачно одређено. Ову чињеницу Вучковић је истакао неколико пута: „Нема времена да се музеј погледа” (Читање градова, 2010: 376); „не можемо дуго да се задржавамо” (Читағе градова, 2010: 377); „ограничено ми је време" (Читање градова, 2010: 379).

Вожња аутобусом са водичем, заустављање аутобуса близу туристичких места, знаменитости и споменика, дозволили су аутору да стекне знања о туђем простору, што му је олакшало касније пешачење улицама шпанских градова.

Улице су кодирана историја градова, вековима нагомилано памћење многих генерација. Архитектура која одражава промене у стиловима и укусима чини сведочанство историје и културе. ${ }^{13}$ Улице су елементи структуре града укорењени у друштвеној свести. Вредност улица као просторних и друштвених форми зависи од способности да се у људској свести створи слика коју ће се лако запамтити. Фактор који доприноси стварању ових слика су физичке особине улице (ширина или дужина), изглед фасада, близина карактеристичних места или објеката и усмереност, која омогућава да се сазна куда улица води. Стварање слика олакшава друштвени карактер улице, дакле ко у њој станује и ко се њом креће. Просторни облик и друштвена димензија улице претварају улицу у знак који омогућава лако памћење одређеног одломка простора. ${ }^{14}$

Аутор је током својих шетњи по градовима обилазио музеје Мадрида (Прадо, Центар савремене уметности краљице Софије), Барселоне (Музеј града Барселоне, Музеј Пикаса, Национални музеј каталонске уметности, Музеј Гаудија, Музеј шпанског села, музеје Толеда и Музеј Салвадора Далија. Писац је видео много споменика као што је симбол Мадрида, споменик Oso y madroño - „фигура медведа који, усправљен на задње ноге, и ослоњен предњим шапама на стабло, убира са његове крошње плодове (веровало се да су то јагоде, али изгледа да је у питању неко друго дрво)" (Читање градова, 2010: 360). У споменике спадају и статуе краљева, као што су били Филип IV, Филип III, Карлос III; статуе истакнутих личности - Колумба, Алваро де Басана (1526-1588), вође Велике Армаде; политичара Емилио Кастелара, књижевника - Сервантеса, Калдерона, Лорке, као и многобројне мадридске фонтане. Писац се такође шетао трговима Мадрида (Капијом сунца, Источним тргом, Тргом Цибеле, Тргом независности), трговима Барселоне

${ }^{13}$ B. Jałowiecki, M. S. Szczepański, Miasto i przestrzeń w perspektywie socjologicznej, Warszawa 2009: 399.

${ }^{14}$ Исто, 397. 
(Каталонским тргом, Шпанским тргом). Видео је хришћанске храмове (цркве и катедрале) у Мадриду, у Толеду, у Барселони, у Ђирони, разгледао је и две толедске синагоге и толедску џамију Баб ал Мардум. Вучковић је навео и многе улице познате туристима (Алкала, Гран Виа, Ла Рамбла), световне зграде (Краљевску палату, Градску кућу, кућу Лопеа де Веге, Кула Луханес, Главну пошту у Мадриду) и друге грађевине - мадридске капије (Пуерта де Толедо и Пуерта де Алкала), мадридску железничку станицу Атоћа, мадридске и барселонске паркове (Ретиро, Цитадела), Палату музике у Барселони, куће које је у каталонској престоници саградио чувени Антонио Гауди, као и кућу у којој је становао од 1906. до 1925.

У црквама и музејима аутор се одушевљавао архитектонским детаљима грађевина и сликама многих стваралаца који су били везани за Шпанију, као Ел Греко, Дијего Веласкес, Хосе Рибера, Франсиско Сурбаран, Естебан Муриљо, Франсиско Гоја, Пабло Пикасо и Салвадор Дали, како и делима страних сликара нпр. Ван дер Вајдена (Скидање са крста), Рубенса (Три грације), Бројгела (Тријумф смрти), Каравађа (Давид и Голијат) итд.

Радован Вучковић даље детаљно описује слике које је видео у музејима и храмовима. Од Ел Грекових слика одабрао је Свето тројство, Витеза са руком на грудима, Пред Христовим распећем, „где је Спаситељ дат у црној одежди, и фигура му је издужена" (Читање градова, 2010: 361) из катедрале у Толеду и Сахрану грофа Оргаза из цркве св. Томе која је „заснована на легенди да се за време сахране (...) десило чудо: свети Стефан и свети Аугустин сишли су с неба да би умрлог понели на небо" (Читање градова, 2010: 362). Од Веласкесових слика обратио је пажњу на Предају Бреде и Лас Менинас или Младе принцеезе, једну од најбољих слика владајуће породице, где се види и лице ствараоца дела. Вучковића је особито заинтересовала Риберина слика Мучење светог Бартоломеја, Сурбаранов Свети Серапион, као и ликови на Муриљовим сликама. Од Гојиних дела писац је навео слику Нага Маја (Нага лепотища) која представља лепотицу „у лежећем положају” (Читање градова, 2010: 356), слику Трећи мај 1808, која показује стрељање родољуба побуњених против Наполеонове војске и композицију Породица Карла IV. У циклусу Гојиних Црних слика Вучковића су привукле фантастичне фигуре које подсећају на чудовишта.

Највеће интересовање од свих дела Пабла Пикаса у мадридском Центру савремене уметности краљице Софије изазива код Вучковића чувена Герника, насликана под утицајем вести о разарању немачким бомбама баскијског града за време грађанског рата. Дело у коме је сликар применио кубистичку разноликост облика, надреалистичку хиперболизацију и 
симултану перспективу, постало је култно достигнуће које показује рушење људских бића и њихове цивилизације. ${ }^{15}$ Од слика у Пикасовом музеју у Барселони Вучковић посвећује пажњу портретима чланова Пикасове породице, класицистичким, кубистичким и експресионистичким сликама. Обратио је пажњу на Пикасову слику која се надовезује на композицију Лас Менинас, што чини покушај суочења са Веласкесовим стваралаштвом. ${ }^{16}$

У музеју Салвадора Далија у Фигересу Вучковић је обратио пажњу на многе предмете, сетио се и других колекција Далијевих дела, надовезао се на разичите периоде стваралаштва сликара који се у школско време бавио импресионизмом, у студентским годинама дадаизмом, футуризмом и кубизмом, а од 1926. сликао је фотографским стилом. ${ }^{17}$ Вучковић је показао нарочито интересовање за слику Привиђење сексуалне привлачности (1934), на којој ,дечак у морнарском оделу посматра из прикрајка огромно женско чудовиште са теретом око врата" (Читање градова, 2010: 385), дело Тристан $u$ Изолда и једну литографију на којој се Сервантесов јунак појавио као фигура у покрету. ${ }^{18}$

Ипак, аутор као историчар књижевности, пре свега је хтео наћи на улицама градова трагове књижевног живота. У Улици Лопеа де Веге угледао је зграду, у којој је становао овај драмски писац, аутор комада Fuenteovejuna, „о побуни сељака Фуенте Овехуне против бахатог племића кога убијају, а краљу нико неће да ода кривца" (Читање градова, 2010: 371) и мање познатог дела Будаласта властелинка (La dama boba), у коме се приказује судбина једног племића кога је очарала сестра његове веренице. Вучковић се задржао испред капије манастира у коме је сахрањен Сервантес, погледао је и споменик Лорке близу Театра комедије и Шпанског театра, видео је споменик Калдерона који га је упутио на размишљања о Калдероновом најпознатијем делу Живот је сан, видео је такође Сервантесов споменик на мадридском Шпанском тргу, као и споменик овог писца у Толеду.

Вучковићеве шетње, које дозвољавају да се реконструише топографија центра Мадрида, Барселоне, Толеда и Ђироне чине својеврстан дијалог са шпанском историјом. Овај дијалог, инспирисан разгледањем зграда, споменика, цркава, одвија се у тесној вези са делима шпанских писаца и са

\footnotetext{
${ }^{15}$ E. L. Buchholz, B. Zimmermann, Pablo Picasso. Życie i twórczość, tłum. Teresa DemuthKaiser, (b. m. w.) 2005: 69.

${ }^{16}$ Исто, 88.

${ }^{17}$ F. Weyers, Salvador Dali. Życie i twórczość, tłum. Oskar, (b. m. w.) 2005: 18-19.

${ }^{18}$ Исто, 78.
} 
српским путописним текстовима о Шпанији чији су аутори већ поменути (Растко Петровић, Јован Дучић, Милош Црњански и Иво Андрић). Такав је случај са коридом, коју Вучковић није могао да види уживо, јер се спектакли одржавају само од маја до октобра, а он је боравио у Шпанији на прелому децембра и јануара. Сумње изазива код Вучковића етичка димензија спектакла који је писац назвао „масакром (...) животиња” (Читање градова, 2010: 354). Аутор помиње чињеницу да су његови претходници „на шпанском путу”, Р. Петровић и М. Црњански, описивали борбе са усхићењем, али њему се арена учинила одбојном. Белешка о краљу Филипу II, кога Вучковић означава као најпознатијег владара, појавила се у тексту само у контексту селидбе шпанске престонице 1561. у Мадрид. Ј. Дучић у свом Писму из Шnaније истицао је безобзирност и строгост овог краља, кога је сматрао за „најнехришћанскију личност у историји” (Читање градова, 2010: 350), а Црњански помиње и краљеву љубав према сликарству. Вучковић, приликом разгледања Гојиних слика, размишља о Андрићевом есеју Гоја који је настао 1928. под утиском изложбе Гојиних слика у Праду, поводом обележавања стоте годишњице сликареве смрти. Разгледајући Ел Грекова платна у Толеду, Вучковић се опет надовезује на Дучићев есеј, где је Крићанин назван „најшпанскијим од свих шпанских сликара” (Дучић, 2008: 301). Радован Вучковић, као и Дучић у свом делу, покушава такође да упореди католицизам са православљем. Шетња уличицама Толеда подсећа писца на пешачење јунака приче Иза мистерије Толеда Растка Петровића, који је у овом граду покушавао да нађе трагове Ел Грековог боравка. За разлику од Петровића, Радован Вучковић није нашао у фасцинантном граду на реци Тахо ништа што би могло потврдити Петровићеву тезу о његовом паду. Године које су делиле Петровићеву посету Толеду од Вучковићевог боравка у овом граду деловале су у корист Толеда који је постао обавезна тачка на туристичкој мапи Шпаније.

Разгледање за кратко време многих музеја, споменика, цркава, пешачење бројним улицама, трговима и парковима дозволило је Вучковићу да само површно „дотакне” стварност, јер од стварног живота увек изолује туристу „филтер који служи само потрошачкој потреби”. ${ }^{19}$

Начин посматрања туђег простора који је одобрио Вучковић одабравши организовану екскурзију, означава пристанак на физичку блискост

${ }^{19}$ Z. Bauman, Ponowoczesność jako źródło cierpień, Warszawa 2000: 149. 
и духовну дистанцу. ${ }^{20}$ Вожње током којих посетиоци гледају свет кроз прозоре аутобуса имају сличну улогу као телевизијски или биоскопски екрани. Такав начин обилажења показује сродност између туризма и спектакла. Туриста који посматрајући простор кроз окна, зауставља се на најпознатијим местима, бежи од стварног живота, а у крајњим случајевима посвећује више пажње фотографисању него разгледању. ${ }^{21}$

Опис простора подређен је захтевима фабуле која се шири у зависности од тога на који начин је организован простор и где се налазе места славна по историјским догађајима, лепим знаменитостима итд. ${ }^{22}$

Вучковић води читаоца одређеним путевима, бележи места на којима се треба зауставити. Просторна блискост објеката одлучује о њиховом суседству у структури текста и зато се у Вучковићевом делу гомилају информације о грађевинама и споменицима које писац види док се шета мадридским, толедским или барселонским улицама.

Свака улица може да постане место збивања, која одређују њен друштвени и симболички карактер. Улица је место становања, рада, друштвеног живота, размене искустава и информација. Она чини сферу симболике града и његових становника, личи на спектакл, у којем учествују појединци као гледаоци, а понекад и као глумци. ${ }^{23}$

Радован Вучковић, који је гледао трку на барселонском шеталишту, на улицама Толеда и Ђироне, дочекивао Нову годину 2010. на мадридском тргу, приметио је да се на улицама стално „нешто (...) изводи” (Читање градова, 2010: 352).

Из чињенице да у записима пресудну улогу има градски простор потиче безброј архитектонских детаља. ${ }^{24}$ Писац, налазећи се у градском простору чија га је архитектура угушила, није имао много прилика да се диви природи. Чудио се мадридској железничкој станици Атоћа која унутра изгледа као тропска башта и барселонским парковима. Ванградским видицима одушевљавао се током путовања из Барселоне у Фигерес и Ћирону, пролазећи

\footnotetext{
${ }^{20}$ B. Jałowiecki, M. S. Szczepański, Miasto i przestrzeń w perspektywie socjologicznej, Warszawa 2009: 355.

${ }^{21}$ E. Morin, Duch czasu, tłum. A. Frybesowa, Kraków 1965: 69.

22 P. Kowalski, Odyseje nasze byle jakie. Droga, przestrzeń i podróżowanie w kulturze współczesnej, Wrocław 2002: 71.

${ }^{23}$ B. Jałowiecki, M. S. Szczepański, op. cit., 2009: 403-405.

${ }^{24}$ P. Kowalski, Odyseje nasze byle jakie, 2002: 71.
} 
„кроз пределе типично приморског пејзажа оскудног биљем и местимично богатог камењем” (Читање градова, 2010: 382).

Боравак у непознатом простору води сталним упоређивањима. „Опис овде (ново, туђе, непознато) изазива контекст тамо (познато, родно, своје, домаће), приморавајући ја да одреди свој став према простору”. 25 Мадрид, с обзиром на сачуване трагове исламске културе (нпр. торањ из XV века у стилу мудехар), асоцира Вучковића, који је потицао из муслиманске Босне, на градове Истока. Бивша арабљанска четврт подсећа га на Сарајево, а за време својих шетњи примећује и трагове исламске уметности (нпр. детаљи на Тријумфалној капији у Барселони).

Кретање по непознатом простору и „неопходност суочења с другим (...) проузрокује (..) раслојавање садашњег времена и многих прошлих времена, на такав начин да су она заједно присутна у тексту". ${ }^{26}$ Прошло време за Вучковића јесте - успомена на детињство и одјеци Шпанског грађанског рата, али такође и тематизација шпанске прошлости које изазивају споменици, историјске личности (сликари, владари, писци), чије присуство писац наслућује током разгледања градова. Одређена географска места покрећу слике историјских и културних простора на које се надовезује аутор. ${ }^{27}$

Фактор који детерминише перцепцију, вредновање и упознавање простора јесте културни капитал - фонд памћења, знања, естетских и етичких вредности која се преносе с колена на колено. ${ }^{28}$ Вучковић се, приказујући одређени одломак стварности, служи како шпанском књижевношћу тако и Дучићевим, Петровићевим, Андрићевим и Црњансковим делима о Шпанији, чије одломке (без фуснота) укључује у своје путничке записе из ове земље.

Начин описивања Шпаније код Вучковића личи на Дучићево Писмо из Шnaније с обзиром на степен засићености историјом и недостатак савремених збивања. Изузетак чине малобројне белешке о уличним представама или дочеку Нове године које везују Вучковића за савременост и истичу његово присуство у простору који описује. Ипак, анонимност гледалаца и глумаца ових уличних представа, као и усамљеност аутора у људској гомили не чини од њега учесника, већ само посматрача, зато Вучковић, као и Дучић, истиче дистанцу која га раздваја и удаљава од туђег простора који описује.

25 D. Kozicka, Wędrowcy światów prawdziwych. Dwudziestowieczne relacje z podróży, Kraków 2003: 78.

${ }^{26}$ Исто.

${ }^{27}$ Исто, 171.

${ }^{28}$ B. Jałowiecki, M. S. Szczepański, Miasto i przestrzeń, 2009: 353. 
Слика Шпаније коју стварају Дучић и Вучковић чини само једну од многих слика страних земаља коју су створили ови писци. Дучићево дело, као и Вучковићеви записи укључени су у збирке есејистичко-путописне прозе, чији су предмет описа географски и културно-језички туђи простори. Оба аутора обележила су ове просторе на сличан начин, истичући улогу градова. Ова улога истиче се већ на нивоу наслова - код Дучића то су Градови $u$ химере, код Вучковића Читање градова.

У оба случаја успомене са путовања нису само културолошкотуристички описи. У њима су присутни бројни трагови европске културе у фактографском и културолошком смислу. ${ }^{29}$ Вучковић, слично Дучићу, ствара урбанистички пејзаж, који је видљив захваљујући његовим промишљањима историје, уметничких (сликарских) и књижевних дела. Читањем културних кодова градова у којима је боравио, Вучковић ствара властиту духовну мапу Европе. $^{30}$

Иако се Јован Дучић описујући Шпанију претежно посветио градићу Авила чијим се улицама шетао, упознајући места везана за лик и делатност песникиње и калуђерице, светице католичке цркве св. Терезе Авилске (15151582), ипак је навео и друге шпанске градове, као Сеговија, Толедо, Сантијаго де Компостела. Док је аутор Писма из Шпаније, презентујући слику ове земље, одабрао временску дистанцу и шпанску историју XVI и XVII века, Радован Вучковић, не одбацујући историјску рефлексију, која се истиче детаљним описима знаменитости (споменика, фасада, цркава) и призивањем историјских личности (краљева, сликара, књижевника, политичара итд.), постаје читаочев водич по савременом Мадриду, Толеду, Барселони, Ђирони. Вучковић своје шетње изводи у тачно одређеном простору ових градова, по схеми која налази свој одраз у картографији. Наводећи оригиналне, шпанске називе делова града (Barrio Gótico), тргова (Puerta del Sol, Plaza de Espaňa, Plaza Mayor, Plaza de Oriente, Plaza de Cibeles, Plaza de Independencia, Plaza de Santa Ana, Plaza de España, Plaza de Catalunya), синагога (Santa María La Blanca, El Tránsito), цркава и катедрала (La Almudena, La Sagrada Familia, Santa María del Mar, Iglesia de San Jeronimo el Real), световних зграда (Torre de los Lujanes, Mercado de San Miguel, Puerta de Toledo, Puerta de Alcalá, Plaza de los Toros de Las Ventas), кућa (Casa Batlló, Casa Milá, Casa de Cisneros),

${ }^{29}$ В. Гвозден, Јован Дучић путописаи. Нови Сад 2003: 214.

30 G. Tešić, www.saglasnik.com/biblioteka-knjizevnost-nauka-kultura-i-umetnost-i/ umetnost- i-kultura/kolekcija-zivotopis/citanje/ 
паркова (Retiro, Ciutadella, Güell) писац тачно и детаљно реконструише план најпопуларнијих туристичких места.

Начин представе простора је везан за детаљан опис објеката грађевина, фонтана, храмова, капела и споменика, као нпр. споменик Сервантесу на Шпанском тргу у Мадриду. Он је

огромне (...) величине и представља читаву композицију споменика, посредством које је скулпторски испричана прича о Сервантесу, али и о Дон Kuхоту и о истоименом јунаку и његовом сапутнику Санчу Панси. Споменик, наиме, у централном делу приказује Сервантеса у седећем положају са књигом у (...) руци. Испред њега су бронзани Дон Кихот на својој Росинанти и Санчо Панса на магарцу. Први у натегнутој пози витеза-ратника, а други подсмешљивог израза лица, сконцентрисаног на свакодневне практичне проблеме. С једне и с друге стране су женске статуе, вероватно неке симболичне инкарнације Дон Кихотове Дулчинеје. При самом врху и на средини споменика су нове групе фигура које представљају сцене из живота великог писца или сцене из његовог најзначајнијег дела (Читање градова, 2010: 366).

Детаљни описи сведоче о томе да је Радован Вучковић осим сопствених импресија и утисака користио и компендије, приручнике и водиче, јер у записима узима у обзир и места која није посетио (као Краљевска палата у Мадриду или Музеј Хуана Мироа у Барселони).

На перцепцију и вредновање простора, осим нивоа образовања и друштвеног положаја, утиче расположење и осећање, а такође и старосна доб, пол и физичка кондиција посетиоца. ${ }^{31}$ Радован Вучковић који је тада имао 75 година, желећи да што ефикасније искористи време боравка, изабрао је начин разгледања који је захтевао добро физичко стање, јер је био повезан са интензивним напором. Да би успео да види што више, писац се често одрицао одмора, а осетивши умор након свакодневног пешачења по граду, пропустио је неке занимљивости, као што су били нпр. позив на вечеру или на спектакл фламенка.

Резултати Вучковићевих познавалачких искустава забележени су у путничким записима у облику детаљних описа, чија лектира захтева од читаоца нарочит напор и пажњу. Уз његове текстове пристаје мисао Виде Огњеновић да путописе треба читати само тада кад се односе на места која читалац познаје, јер тек тада успева да успостави дијалог с писцем и изазове

${ }^{31}$ B. Jałowiecki, M. S. Szczepański, Miasto i przestrzeń, 2009: 353. 
интересовање тамо где се мишљења писца и читаоца поклапају, а где се пак разликују. $^{32}$

Код читаоца који не познаје места које Вучковић описује лектира његове књиге Читање градова може изазвати умор. Читалац лута кроз шуму детаља, као и њихов аутор - кроз улице непознатих градова. Велики број чињеница као што су називи улица, тргова, грађевина, цркава, детаљно описани споменици, храмови, капеле, капије, водоскоци, фасаде зграда, музејске колекције и слике, стварају лавиринт, у којем читалац Вучковићеве књиге може да залута на исти начин као што би залутао шетајући кривудавим уличицама непознатог града.

Małgorzata Filipek

\section{SPAIN IN RADOVAN VUČKOVIĆ'S TRAVEL PROSE}

\section{Summary}

The subject of this work is the image of Spain in Read Cities by Radovan Vučković. The writer, visiting Spanish cities such as Madrid, Toledo, Barcelona and Gerona, refers in the book Read Cities to other Serbian authors (Petrović, Andrić, Crnjanski, Dučić) who wrote about Spain. The structure of Vučković's book is reminiscent of the volume Cities and Chimeras by Jovan Dučić, where the historical reflection is more important than the present. Vučković infused his book with so many architectural details, descriptions of buildings, monuments, and paintings that the reader may get lost in them, like a tourist in an unknown city.

Keywords: Spain, image, prose, Vučković, history, tourist, Dučić

\section{ЛИТЕРАТУРА}

Barthes, R. (2000). Mitologie, thum. A. Dziadek, Warszawa: Wydawnictwo Aletheia.

Bauman, Z. (2000). Ponowoczesność jako źródło cierpień, Warszawa: Wydawnictwo Sic!.

Buchholz, E.L. - Zimmermann, B. (2005). Pablo Picasso. Życie i twórczość, tłum. Teresa Demuth-Kaiser, (b. m. w.): Wydawnictwo Inne.

Gvozden, V. (2003). Jovan Dučić putopisac. Novi Sad: Svetovi (Štampano ćirilicom!)

Dučić, J. (2008). Pismo iz Španije. Gradovi i himere. Beograd: Dereta (Štampano ćirilicom!)

${ }^{32}$ В. Огњеновић, Путовање у путопис, Зрењанин 2005, 116-117. 
Jałowiecki, B. - Szczepański M.S (2009). Miasto i przestrzeń $w$ perspektywie socjologicznej, Warszawa: Wydawnictwo Scholar.

Kowalski, P. (2002). Odyseje nasze byle jakie. Droga, przestrzeń i podróżowanie w kulturze wspótczesnej Wrocław: Wydawnictwo Atla.

Kozicka, D. (2003). Wędrowcy światów prawdziwych. Dwudziestowieczne relacje z podróży, Kraków: Wydawnictwo Universitas.

Miłkowski, T. - Machcewicz, P. (1998). Historia Hiszpanii, Wrocław: Wydawnictwo Ossolineum.

Morin, E. (1965). Duch czasu, tłum. A. Frybesowa, Kraków: Wydawnictwo Znak.

Ognjenović, V. (2005). Putovanje u putopis, Zrenjanin: Gradska narodna biblioteka Žarko Zrenjanin. (Štampano ćirilicom!)

Tešić, G., www.saglasnik.com/biblioteka-knjizevnost-nauka-kultura-i-umetnosti/umetnost-i-kultura/kolekcija-zivotopis/citanje/.

Weyers, F. (2005), Salvador Dali. Życie i twórczość, tłum. Oskar, (b. m. w.), Wydawnictwo Könemann.

Wojciechowski, K.H. (1986), Problem percepcji i oceny estetycznej krajobrazu, Lublin: Wydawnictwo UMCS.

Vučković, R. (2010). Čitanje gradova. Dnevnik putovanja, Beograd: Službeni glasnik. (Štampano ćirilicom!) 